\title{
FENOMENA ABORSI DAN HAK HIDUP ANAK \\ DALAM PERSPEKTIF ISLAM
}

\author{
Ilfi Nur Diana \\ Dosen Fakultas Ekonomi UIN Malang
}

\begin{abstract}
Abstrak
Abortion is very where today, even the womwn who has husband or rich family do it by various reasons. Abortion is a mistreatment and a criminal to the mankind. Al-Quran respect so much to human right which is given by Allah to the mankind, including having right to live. That's why having right to live for children must be protected as early as possible, taking soul of the children either before or after being born is high level of prohibition in Islam, even many different opinions, one of them is it's allowed to be done before the trob is found.
\end{abstract}

\section{A. Pendahuluan}

Kemampuan reproduksi perempuan seringkali dihadapkan pada etika yang bersifat dilematis, karena terkait dengan sebuah pilihan yang berdampak pada kehidupan dan kematian janin. Dalam Islam, permasalahan tersebut berkaitan dengan fiqih, karena etika dalam Islam tidak dapat dipisahkan dari agama dan sepenuhnya dibangun di atas agama. Begitu pula dengan sains dan teknologi tidak dapat dipisahkan dari etika. Dalam bidang biomedis, terdapat kecenderungan untuk berusaha mengalahkan kematian dan memanipulasi kehidupan, seperti halnya mengakhiri hidup dengan cara aborsi, euthansia, dan memperpanjang hidup dengan transplantasi organ tubuh dan alat pernapasan. Di sinilah kaum muslim berhadapan dengan rangkaian masalah etika yang juga memiliki implikasi hukum.

Patut dicatat, bahwa para ulama mengklasifikasikan tiga macam kejahatan, pertama, kejahatan terhadap manusia seutuhnya. Yang termasuk jenis kejahatan 
ini adalah semua kejahatan yang menghilangkan nyawa manusia. Kedua, kejahatan yang bukan ditujukan pada manusia seutuhnya tetapi pada bagianbagian tertentu dari anggota tubuhnya, seperti melukai secara fisik. Ketiga, kejahatan pada manusia dan bukan manusia di sisi lain, yang termasuk kategori ini adalah gangguan pada janin. Meskipun pembunuhan terhadap janin tidak termasuk kategori pembunuhan manusia seutuhnya, tetapi tetap saja merupakan bentuk kejahatan dan perbuatan dosa. ${ }^{1}$ Lantas bagaimana dengan aborsi? Semua literatur hukum Islam sepakat bahwa aborsi merupakan perbuatan aniaya dan merupakan kejahatan terhadap makhluk hidup. Namun ulama berbeda pandangan tentang janin yang sudah bernyawa dengan janin yang belum bernyawa, atau janin yang sudah sempurna bentuknya dengan yang belum sempurna.

\section{B. Aborsi dan Permasalahannya}

Aborsi sebenarnya telah lama dikenal dalam sejarah manusia, seperti halnya di China pada tahun 2700 SM telah banyak digunakan obat-obatan secara bebas untuk menggugurkan kandungan, sementara itu undang-undang Assyria tahun 1500 SM telah mengutuk aborsi dengan kalimat berikut :

"Setiap wanita yang menyebabkan jatuhnya sesuatu yang ditahan oleh rahimnya, harus diperiksa, dihukum dan ditembak pada tiang pancang dan tidak boleh dikubur"2.

Aborsi adalah suatu perbuatan untuk mengakhiri masa kehamilan dengan mengeluarkan janin dari kandungan, sebelum janin dapat hidup di luar kandungan atau dikenal dengan اسقاط الحمل. Adapun cara aborsi dapat dilakukan dengan cara

\footnotetext{
${ }^{1}$ Mohsin Ibrahim, Abul Fadol, terjemah, Sari Meutia, Abrosi, Kontrasepsi dan mengatasi kemandulan, Bandung, Mizan,1997;125

${ }^{2}$ Simmons, Paul D, Birt and death Bioethical Decision-Making, Philadelphia, The Westminser Press, 1983;67.
} 
curratage \& dilatage (C\&D), dengan alat khusus/dikiret, aspirasi (penyedotan isi rahim dengan pompa kecil), hysterotomi (operasi), minum obat, dan bantuan dukun pijat.

Aborsi ada dua macam, pertama abortus spontan (keguguran dengan sendirinya atau tidak disengaja), aborsi macam ini tidak menjadi kontroversi. Kedua abortus buatan/profocatus (keguguran atas usaha manusia). Aborsi type kedua ini mempunyai implikasi etik, hukum, dan agama. Aborsi ini ada 2 macam, yatu abortus indirectus (karena indikasi medis), dan abortus kriminal (pengguguran kandungan sebagai tindak pidana, sebagaimana diatur dalam KUHP pasal 346- 349).

Adapun dasar hukum yang menjerat pelaku aborsi adalah :

\section{Pasal 346}

Wanita yang dengan sengaja menyebabkan gugur atau mati kandungannya, atau menyuruh orang lain menyebabkan itu, dipidana penjara selama-lamanya 4 tahun.

2. Pasal 347

Barang siapa dengan sengaja menyebabkan gugur atau mati kandungan seorang wanita tidak dengan izinnya, maka dipidana 12 tahun

3. Pasal 348

Jika dengan izin wanita itu, dipidana 5 th 6 bln.

4. Pasal 349 :

Dokter atau bidan atau juru obat yang membantu maka pidana yg ditentukan tersebut ditambah $1 / 3$, dicabut hak prakteknya. 
Faktor pendorong dilakukannya aborsi :

1. Atas dasar indikasi medis : untuk menyehatkan/kehidupan ibu.

2. Atas dasar indikasi sosial : kehamilan di luar nikah, perkosaan, kesulitan ekonomi, kegagalan alat kontrasepsi padahal tidak mau hamil, pilihan karier, dan pilihan jenis kelamin.

Dampak Kemungkinan yang akan terjadi dengan adanya aborsi adalah :

1. Timbul luka dan infeksi pada dinding alat kelamin dan merusak organ-organ di dekatnya.

2. Robek mulut rahim bagian dalam

3. Dinding rahim bisa tembus

4. Pendarahan

5. Infeksi.

Organisasi Kesehatan Dunia (WHO) memperkirakan di seluruh dunia terjadi 20 juta kasus aborsi tidak aman, 13\%nya berakhir dengan kematian. Di ASEAN, kasus aborsi sebanyak 2.800.000, atau 15\% (8.100)nya perempuan meninggal akibat aborsi tak aman. WHO memperkirakan dari 200 juta kehamilan pertahun di dunia sekitar $38 \%$ (75 juta) merupakan kehamilan tak diinginkan (TTO). $11 \%$ (8 juta) dari mereka karena mengalami kegagalan kontrasepsi sementara sisanya karena mereka tidak menggunakan kontrasepsi.

Dari 75 perempuan yang mengalami KTD, Dua Pertiga (50 juta) akan mengakhiri kehamilannya dengan aborsi disengaja dan sekitar 60\% (30 juta) melakukan secara aman dengan bantuan tenaga profesional. Sedang sisanya $40 \%$ I 
20 juta dilakukan secara tidak aman oleh tenaga yang tidak berkompeten. (WHO, 2000a).

Di Indonesia, ditemukan 2 juta kasus aborsi tidak aman atau unsafe abortion. Per tahun Pelakunya; $87 \%$ menikah, $13 \%$ belum menikah ${ }^{3} .67 \%$ melakukan upaya aborsi sendiri, dan sebagian berakhir dengan kematian. Angka Kematian Ibu (AKI) di Indonesia tergolong sangat tinggi, 307/100.000 kelahiran hidup. Bandingkan dengan Malaysia 39, Filipina 170, Thailand 44 per 100.000 kelahiran hidup. ${ }^{4}$

Beberapa hasil penelitian lapangan juga menunjukan bahwa jumlah remaja usia 10 - 24 tahun sudah mencapai 62 juta (30,3\% dari total penduduk Indonesia) menurut SP 2003. Dan $15 \%$ dari mereka telah melakukan hubungan seks diluar nikah. Hingga maret 2007 terdapat 8.988 kasus Aids dan 5.640 kasus HIV positif di Indonesia. 57, $1 \%$ dari kasus tersebut terjadi pada remaja 15 - 29 tahun $(37,8 \%$ terinfeksi melalui hubungan seks yang tidak aman dan 62,2\% terinfeksi melalui penggunaan narkoba dengan jarum suntik). ${ }^{5}$

Peneliti dari FISIP UNPAD Bandung, Indraswati menyimpulkan bahwa $85 \%$ pelaku Aborsi sudah menikah, (1997). Catatan dari yayasan kesehatan perempuan (YKP) menegaskan bahwa $67 \%$ dari 1434 pelaku aborsi melakukan aborsi dengan cara pergi ke Dukun bayi, minum jamu / pil sebelum datang ke Klinik / rumah sakit (2002). Angka kematian ibu di Indonesia cukup tingi mencapai 373 per 100.000 kelahiran hidup (1997) dan meningkat menjadi 396 pada tahun 2001 sementara posisi pada tahun 2003 dapat ditekan kembali menjadi

\footnotetext{
${ }^{3}$ Budi Utomo, 2002 dan YKP, 2003

${ }^{4}$ UNFPA. State of The World Population Report, 2001.

${ }^{5}$ PKBI, Mei 2007
} 
307 yang merupakan Angka tertinggi di Asia Tenggara dan negara-negara Islam lainnya. Dari data tersebut yang dilaporkan akibat pendarahan sebesar $(46,7 \%)$, keracunan kehamilan (14,5\%), infeksi $8 \%$. Kebanyakan disebabkan karena ibu hamil ditolong oleh dukun atau tenaga yang tidak terlatih (aborsi tidak aman). ${ }^{6}$

Survei Kesehatan Rumah Tangga ${ }^{7}$ konstribusi aborsi dalam menyokong tingginya angka kematian Ibu mencapai $11 \%$. Sementara Prof. Dr. Azrul Azwah, Dirjen bina Kesnas Depkes, memperkirakan angka $50 \%$ AKI akibat aborsi tidak $\operatorname{aman}^{8}$.

Dari fenomena aborsi ini, ternyata pihak perempuanlah yang sangat rentan terhadap resiko gangguan kesehatan bahkan kematian. Perempuan menjadi obyek penderita, yang merasakan sakit dan ketidaknyamanan dalam tubuhnya, bahkan juga resiko kematian. Perempuan selalu berada dalam posisi yang dipersalahkan secara hukum, agama maupun norma masyarakat. Kondisi tersebut mencerminkan fakta bahwa persoalan aborsi hanya dibebankan kepada perempuan, padahal seharusnya menjadi tanggung jawab negara.

Lalu mengapa aborsi makin marak terjadi? Bahkan aborsipun juga dilakukan oleh perempuan yang sudah bersuami, atau oleh keluarga mapan sekalipun. Alasannya antara lain dikarenakan suami isteri sibuk kerja sehingga tidak ada waktu mengurus anak lagi, atau dengan alasan kehawatiran tidak dapat memberikan pendidikan yang layak pada anak, atau juga karena kecacatan yang akan disandang oleh janin yang dikandungnya jika sampai dilahirkan.

\footnotetext{
${ }^{6}$ SDKI, 2002/2003

${ }^{7}$ SKRT, 1995

${ }^{8}$ Kompas, Desember 2003
} 


\section{Anak dan Hak hidup}

Mengapa aborsi dilarang? karena aborsi menyangkut hak hidup calon sorang anak. Sebenarnya sejak kapankah seorang anak mempunyai hak untuk hidup? Apakah setelah dilahirkan? Ataukah sejak terjadinya proses pembuahan? Ataukah setelah terbentuknya janin? Atau bahkan setelah janin itu bernyawa? Pertanyaan ini selalu menimbulkan kontroversi. Namun terlepas dari kontroversi itu, perlu dipahami terlebih dahulu tentang janin itu sendiri. Menurut ilmu kedokteran, janin terbentuk setelah kehamilan berusia delapan minggu sampai saat kelahiran. Pada tahap delapan minggu ini, janin mempunyai karakteristik penting manusia. ${ }^{9}$

Imam Syafi'i berpandangan bahwa disebut janin ketika tahap al-mudghah (gumpalan daging). Pada tahap ini janin disebut sebagai calon manusia yang sudah memiliki karakteristik manusia, seperti jari tangan, mata, kuku dan lainlain. Al-Nuwairy mengatakan bahwa yang disebut dengan janin jika sesuatu yang terdapat dalam rahim tersebut sudah diberi ruh. ${ }^{10}$ Dengan demikian, pemahaman janin yang diberikan Imam Syafi'i adalah yang paling mendekati pemahaman menurut ilmu kedokteran.

Ada empat tahap perkembangan janin, yaitu : Pertama Zigot, yaitu ovum yang telah dibuahi oleh sperma laki-laki dalam saluran telur perempuan. Zigot tinggal di situ kurang lebih tiga hari, saat itulah pembelahan sel dimulai. Kedua Blastosis, yaitu tahap yang dimulai dengan penanaman rahim, yang mana

\footnotetext{
${ }^{9}$ Munso Ronald, Intervention and Reflection, Basic Issues in Medical Ethics, California, Wadsworth Publishing Co., Edisi ke2,1983, 41.

${ }^{10}$ Muhamad Salam Madzkur, al-Janin wa al-ahkam al-Mutaalliqah bihi fi Fiqhi al-Islam, Kairo, Dar al-Nahda al-Arabiyah, 1969;32.
} 
pembelahan sel terus berlangsung dengan cepat. Ketiga embrio, yaitu tahap yang dimulai terjadi dua minggu setelah proses pembuahan. Keempat adalah janin, yaitu tahap delapan minggu sampai lahirnya, dan selama ini terus terjadi pertumbuhan dan perkembangan tetapi tidak ada tambahan baru. ${ }^{11}$

Ayat al-Quran yang merujuk pada perkembangan janin adalah sebagai berikut :

1. Diciptakan dari saripati tanah: Q.S Al-Sajadah/32:7, Al-Mukminun/23:12, S.S Al-Hajj/22:5.

2. Pertemuan antara sperma dan ovum: Al-Insaan/76:2, Al-Mukminun/ 23:13, Al-Qiyamah/75:37, Al-Thaariq/86:5-8.

3. Menjadi segumpal darah: Al-Qiyamah/75:37-38.

4. Menjadi segumpal daging: Al-Mukminun/23:14

5. Tulang belulang yang dibungkus daging: Al-Mukminun/23:14

6. Roh ditiupkan: Al-Mukminun/23:14, Al-Sajdah/32:9.

Paling sedikit ada dua Hadist yang merujuk langsung pada perkembangan janin, yaitu :

1. Tujuh hari pembuahan:

"Sesungguhnya jika Allah ingin menciptakan manusia, maka ia mempertemukan antara laki-laki dan perempuan yang memancarkan sperma ke setiap pembuluh dari anggota tubuhnya, jika sudah sampai pada hari ke tujuh Allah akan menghimpunnya pada setiap pembuluh, kecuali pada penciptaan Adam". (HR At-Thabrani).

2. Empat puluh hari pada setiap tahapan:

"Rasulullah menceritakan kepada kami sesungguhnya seseorang dari kamu kejadiannya dikumpulkan dari perut ibumu selama 40 hari berupa

${ }^{11}$ Simmon, P.D. Birt and Death;79-80. 
nuthfah, kemudian menjadi segumpal darah ('alaqah), dalam waktu yang sama, kemudian menjadi segumpal daging (mudghah), juga dalam waktu yang sama. Sesudah itu, malaikat diutus untuk meniupkan roh ke dalamnya dan diutus untuk melakukan empat kalimat, yaitu mencatat rizkinya, usianya, amal perbuatannya dan celaka atau bahagia" (HR. Muslim).

Dengan demikian, janin harus dilindungi, karena janin mempunyai hak untuk hidup. Hal ini diperkuat dengan fakta bahwa semua madzhab memerintahkan untuk menunda pelaksanaan hukuman mati bagi perempuan hamil sampai melahirkan, bahkan menurut Syafi'i, perlu pembedahan perut mayat perempuan hamil untuk mengambil janin yang masih hidup. Begitu pula dengan janin yang lahir mati, harus dikebumikan. Ibnu Abidin mnjelaskan bahwa janin yang tidak mengeluarkan suara saat lahir harus dimandikan, diberi nama, dibungkus dalam selembar kain kafan dan dikuburkan. Hal ini wajib dilakukan pada janin yang sempurna maupun belum sempurna. ${ }^{12}$ Ini sebagai salah satu tanda bahwa Islam sangat mendukung hak hidup janin dan menghargai hak hidup makhluk yang berpotensi untuk hidup sebagai manusia (muhayyi' lilhayyi).

Islam sangat menjunjung tinggi kesucian kehidupan. Sejumlah ayat membicarakan hal ini, yaitu :

a. Dan sesungguhnya telah Kami muliakan anak-anak Adam, Kami angkut mereka di daratan dan di lautan, Kami beri mereka rezki dari yang baikbaik dan Kami lebihkan mereka dengan kelebihan yang sempurna atas kebanyakan makhluk yang telah Kami ciptakan (QS. 17:70)

b. Dan janganlah kamu membunuh anak-anakmu karena takut kemiskinan. Kamilah yang akan memberi rezki kepada mereka dan juga kepadamu. Sesungguhnya membunuh mereka adalah suatu dosa yang besar (QS. 17:31).

c. Oleh karena itu Kami tetapkan (suatu hukum) bagi Bani Israil, bahwa: barangsiapa yang membunuh seorang manusia, bukan karena orang itu (membunuh) orang lain, atau bukan karena membuat kerusakan dimuka

\footnotetext{
${ }^{12}$ Ibnu Abidin, Muhamad Amin, Hasyiah Radd al-Muhtar, Beirut, Dar al-Fikri, 1979, 228.
} 
bumi, maka seakan-akan dia telah membunuh manusia seluruhnya. Dan barangsiapa yang memelihara kehidupan seorang manusia, maka seolaholah dia telah memelihara kehidupan manusia semuanya. Dan sesungguhnya telah datang kepada mereka rasul-rasul Kami dengan (membawa) keterangan-keterangan yang jelas, kemudian banyak diantara mereka sesudah itu sungguh-sungguh melampaui batas dalam berbuat kerusakan dimuka bumi (QS.5: 32).

Dari ayat-ayat tersebut jelas, bahwa kehidupan manusia itu suci sehingga tidak dapat diakhiri kecuali suatu sebab, seperti dalam eksekusi hukuman mati atau dalam perang, atau dalam pembelaan diri yang dibenarkan. Menghilangkan nyawa anak baik sebelum atau setelah dilahirkan karena takut kemiskinan atau takut tidak dapat memenuhi hak ekonomi anak, merupakan sesuatu yang dikecam keras dalam Islam. Tentu saja bukan faktor ekonomi belaka yang menyebabkan ketidakbolehan tersebut, faktor lain semisal menutupi aib karena hamil di luar nikah, atau kehamilan yang tidak dikehendaki karena kesibukan yang luar biasa ataupun karena usia dini juga menjadi salah satu faktor ketidakbolehan menghilangkan hak hidup anak. Lantas bagaimana dengan aborsi yang kini kian marak dilakukan oleh masyarakat kita?

\section{Pandangan Ulama tentang Aborsi}

Sebelum Islam datang, pada masa Jahiliyah, kaum Arab mempunyai tradisi mengubur hidup-hidup bayi yang baru dilahirkan sebagaimana yang termaktub dalam alquran surat al-Takwiir (8-9). kemudian Islam mengutuk dan

menentang tradisi Jahiliyah ini. ${ }^{13}$ Pada perkembangan selanjutnya fenomena pembunuhan bayi tidak dilakukan pada bayi yang sudah dilahirkan tetapi dengan

${ }^{13}$ QS. Al-Israa', 17:31 
cara membunuh calon-calon bayi yang akan dilahirkan. Dalam istilah Fiqh disebut al-thorhu, imlash, isqoth, dan ijhadl.

Adapun pandangan ulama fikih tentang aborsi adalah :

1. Sebelum penyawaan (qabla nafkhi al-ruh), yakni masih berupa gumpalan darah (40-80 hari) atau gumpalan daging (80-120 hari) maka pendapat ulama beragam, yaitu :

a. Al-Ghozali dan Ibnu Immad mengharamkan aborsi ini, karena gumpalan itu akan menjadi makhluk yang bernyawa. Pendapat ini didukung oleh Ibnu Hajar al-Haytami. ${ }^{14}$ Al-Ghazali menyatakan bahwa tindakan azal merupakan hal yang tidak baik, apalagi jika sudah terjadi proses pembuahan, karena nuthfah merupakan sesuatu yang berpotensi untuk menjadi makhluk yang bernyawa. Ini dijadikan dasar ulama lain bahwa aborsi haram hukumnya sejak terjadi pembuahan.

b. Mahmud Syaltut : Haram aborsi Sejak bertemunya sel sperma dan ovum/sekalipun belum bernyawa.

c. Imam Abu Ishaq al-Mawarzi menyatakan boleh hukumnya aborsi ini, karena gumpalan tersebut belum dikatakan makhluk yang bernyawa. Pendapat ini didukung Imam Romli. ${ }^{15}$

2. Sesudah penyawaan ( $b a^{\prime} d a$ nafkhi al-ruh), yakni kandungan yang sudah berumur 120 hari, semua ulama fikih sepakat mengharamkan sekalipun untuk menyelamatkan nyawa sang ibu.

\footnotetext{
${ }^{14}$ Tuhfatu al-Thullab Tuhfatu al-Muhtaj, VIII;241

${ }^{15}$ Ghuraru al-Bahiyyah V;331, Ianatu al-Tholibin IV;130, Fatawa syekh Sulaiman al-Kurdi:201
} 
a. Al-Zuhaily menyatakan, bahwa tidak satupun dari empat madzhab yang membolehkan aborsi sesudah penyawaan. Tidak boleh membunuh seseorang untuk menyelamatkan orang lain.

b. Ibnu Taimiyah ${ }^{16}$ berpandangan bahwa menggugurkan kandungan adalah haram dan tergolong dosa besar, sama dengan membunuh bayi yang sudah dilahirkan, sebagaimana dinyatakan dalam al-Quran. ${ }^{17}$

Akan tetapi menurut pendapat yang dinuqil oleh Imam Ibnu Hajar al-Haytami dalam kitab Tuhfatu al-Muhtaj dari sebagian ulama madzhab Hanafi, bahwa hukum menggugurkan kandungan secara mutlak diperbolekan meskipun kandungan berusia 120 hari. ${ }^{18}$ Namun pendapat ini diragukan kebenarannya oleh Ibnu Abdil Haq al-Sanbathi. Ia menyatakan; “aku menanyakan masalah ini kepada sebagian ulama madzhab Hanafi dan ternyata pendapat tidak diakui". ${ }^{19}$ Meskipun pendapat ini diragukan kebenarannya oleh sebagian ulama akan tetapi syekh Sulaiman al-Kurdi tetap memperbolehkan untuk mengikutinya. Dengan demikian pendapat ini layak dijadikan sebagai solusi ketika menghadapi kondisi yang mengharuskan dilakukan aborsi untuk menyelamatkan nyawa sang ibu, ( ارتكاب اخف الضررئن واجب), dengan syarat direkomendasi kurang lebih dua ahli medis muslim.

\section{E. Penutup}

Fenomena aborsi khususnya di Indonesia bagaikan fenomena gunung es, yang tampak di permukaan hanyalah sedikit, dan justeru banyak yang terselubung

\footnotetext{
${ }^{16}$ Ibnu Taymiyyah III; 678

${ }^{17}$ QS. Al-Takwiir,81; 8-9, dan al-Israa', 17:31

${ }^{18}$ Tuhfatu al-Muhtaj IX;21, Ianatu al-Tholibin IV;130

${ }^{19}$ Fatawa Syekh Sulaiman al-Kurdi;201
} 
yang tidak terdeteksi oleh masyarakat dan pihak yang berwajib. Dalam tindakan aborsi ini, perempuanlah yang banyak menanggung resiko, baik resiko kesehatan, kematian, hukum, agam, maupun sanksi sosial.

Al-Quran sangat menghargai hak asasi yang diberikan oleh Allah SWT kepada hambanya, termasuk hak hidup. Oleh sebab itu hak hidup anak harus dilindungi sejak dini, menghilangkan nyawa anak baik sebelum atau setelah dilahirkan, merupakan sesuatu yang dikecam keras dalam Islam, sekalipun ulama berbeda pendapat tentang kebolehan aborsi sebelum ada denyut jantungnya.

Untuk meminimalisir aborsi yang kian marak terjadi maka harus ada upaya simultan baik dari masyarakat, pemerintah, LSM, para tokoh dan kiyai. Adapun upaya yang dapat dilakukan adalah :

1. Upaya Hukum

Mengeluarkan undang-undang aborsi, penegakan hukum, Memberikan bimbingan dan penyuluhan hukum.

2. Gerakan sosial keagamaan

Peran ahli agama menyadarkan ummatnya agar terhindar dari kehamilan yang tidak diinginkan yang kemudian dapat menimbukan tindakan aborsi, juga pada para medis agar tidak gegabah melakukan tindakan aborsi tanpa sebab-sebab yang diperbolehkan oleh agama, yaitu penyelamatan jiwa sang ibu. 


\section{DAFTAR PUSTAKA}

D, Simmons, Paul, Birt and death Bioethical Decision-Making, Philadelphia, The Westminser Press, 1983, 67.

Ibrahim, Mohsin, Abul Fadol, terjemah, Sari Meutia, Abrosi, Kontrasepsi dan mengatasi kemandulan, Bandung, Mizan,1997;125.

Ronald, Munso, Intervention and Reflection, Basic Issues in Medical Ethics, California, Wadsworth Publishing Co., Edisi ke2,1983, 41.

Salam, Madzkur, Muhamad, al-Janin wa al-ahkam al-Mutaalliqah bihi fi Fiqhi al-Islam, Kairo, Dar al-Nahda al-Arabiyah, 1969, 32.

Fatawa syekh Sulaiman al-Kurdi

Ghuraru al Bahiyyah, V,

Ianatu al-Tholibin IV,

Tuhfatu al-Thullab IX

Tuhfatu al-Muhtaj, VIII,

Taymiyyah, Ibnu III

Budi Utomo, 2002

Kompas, Desember 2003.

PKBI, Mei 2007.

Pradono dkk. 2001.

SDKI, 2002/2003

UNFPA. 2001. State of The World Population Report.

WHO: Gulardi, 2001.

WHO, 1998.

YKP, Mei 2007. 
YKP, 2003. 